\title{
FILSAFAT MANUSIA : SEBUAH KAJIAN TEKS DAN KONTEKS DALAM MEMAHAMI HAKIKAT DIRI
}

\author{
Oleh : \\ I Gusti Made Widya Sena \\ Institut Hindu Dharma Negeri Denpasar \\ Email: gusti_sena@yahoo.com
}

\begin{abstract}
Abstrak
Manusia sesungguhnya memiliki dua tubuh saat dilahirkan di dunia ini, yakni tubuh materi dan tubuh spiritual. Tubuh materi adalah wujud bentuk fisik-jasmani yang bersifat kasar dan berfungsi untuk menjalankan segala bentuk keinginan dari panca indera, sistem pernapasan, sistem pencernaan, otot, jaringan saraf, peredaran darah dan lainnya. Sedangkan tubuh spiritual adalah tubuh psikis yang bersifat halus dan terdiri dari tubuh kausal (buddhi), tubuh supra kausal (ego halus) dan atman.

Dilahirkan sebagai manusia merupakan suatu kebahagiaan yang utama dalam hidup karena dengan dilahirkan ke dunia, seseorang diberikan kesempatan dalam hidupnya untuk mencapai hakikat diri dengan melakukan dan meningkatkan karma, bhakti, jnana hingga pada akhirnya mencapai kontemplasi dengan menyadari tentang hakikat diri dan atman dalam tubuhnya. Hal inilah yang memberikan kebahagiaan untuk dilahirkan menjadi manusia dibandingkan dengan kelahiran menjadi makhluk lainnya di dunia
\end{abstract}

Kata Kunci : Filsafat, Manusia dan Hakikat diri

\begin{abstract}
Humans actually have two bodies when born in this world, namely the material body and spiritual body. The material body is a form of physical-physical form that is crude and serves to carry out all forms of desires from the five senses, the respiratory system, the digestive system, muscles, neural networks, blood circulation and others. Whereas the spiritual body is a psychic body that is subtle and consists of a causal body (buddhi), a supra causal body (subtle ego) and atman.

Born as a human being is the ultimate happiness in life because by being born into the world, a person is given the opportunity in his life to achieve the essence of himself by doing and increasing karma, bhakti, jnana to finally achieve contemplation by realizing the nature of self and atman in his body. This is what gives happiness to be born into a human being compared to being a creature in the world
\end{abstract}

Key words: Philosophy, Human, Self

\section{PENDAHULUAN}

Banyak sekali pertanyaan yang terlintas dalam benak kita saat pikiran mulai ditujukan pada sang diri. Pertanyaan-pertanyaan seperti: siapakah saya? mengapa saya dilahirkan di dunia ini? apakah saya memiliki kebebasan dalam hidup? sejauhmana beban yang harus saya pikul? apa tujuan saya dilahirkan? dan bagaimana kedudukan saya dalam dunia ini? adalah sebagian kecil dari ratusan, dan bahkan mungkin ribuan pertanyaan yang terlintas dalam benak kita ketika seseorang sejenak untuk mengistirahatkan panca indera dari kesibukan tubuh jasmaninya.

Sesungguhnya semakin seseorang mengistirahatkan panca inderanya, maka akan 
semakin banyak pertanyaan yang akan ditemui dalam pikirannya sebagai akibat dari apa yang disaksikan dan dilakukan semasa masih menikmati keindahan di luar inderanya. Perubahan-perubahan pikiran itu terjadi karena panca indera sebagai alat pemberi dan penerima impuls dari dan ke dunia luar terikat oleh pengaruh obyek materi sebagai bentuk simbol maya. Tidak sedikit yang pada akhirnya melupakan hakikat dirinya sebagai bagian dari alam semesta dan juga bagian dari kesadaran Tuhan.

Manusia sesungguhnya memiliki dua tubuh saat dilahirkan di dunia ini, yakni tubuh materi dan tubuh spiritual. Tubuh materi adalah wujud bentuk fisik-jasmani yang bersifat kasar dan berfungsi untuk menjalankan segala bentuk keinginan dari panca indera, sistem pernapasan, sistem pencernaan, otot, jaringan saraf, peredaran darah dan lainnya. Sedangkan tubuh spiritual adalah tubuh psikis yang bersifat halus dan terdiri dari tubuh kausal (buddhi), tubuh supra kausal (ego halus) dan atman.

Dilahirkan sebagai manusia merupakan suatu kebahagiaan yang utama dalam hidup karena dengan dilahirkan ke dunia, seseorang diberikan kesempatan dalam hidupnya untuk melakukan dan meningkatkan karma, bhakti, jnana hingga pada akhirnya mencapai kontemplasi dengan menyadari tentang hakikat diri dan atman dalam tubuhnya. Hal inilah yang memberikan kebahagiaan untuk dilahirkan menjadi manusia dibandingkan dengan kelahiran menjadi makhluk lainnya di dunia.

Berdasarkan latar belakang di atas, penulis tertarik mengangkat tulisan ini karena sebelumnya belum pernah ada tulisan atau artikel ilmiah terkait tema yang penulis angkat. Selain itu dengan menulis artikel ini diharapkan agar nantinya artikel-artikel ilmiah yang sejenis semakin banyak berkembang dan memberikan sumbangan bagi dunia pengetahuan dan filsafat.

\section{PEMBAHASAN}

\subsection{Konsep Filsafat}

Menurut Rahman dalam bukunya yang berjudul Buku Pintar Sejarah Filsafat Barat (2013: 18) kata "filsafat" yang kita gunakan dewasa ini berasal dari bahasa Yunani, yakni "philosophia". Kata filsafat ini dalam bahasa Arab disebut falsafah dan dalam bahasa Inggris disebut philosophy. Dalam tradisi berfilsafat, hampir seluruh Filsafat yang berasal dari kata philosophia itu, terdiri dari dua kata yaitu kata philein yang berarti 'cinta' (love), dan kata sophia yang berarti 'kebijaksanaan' (wisdom). Berdasarkan uraian etimologis tersebut, maka kata filsafat yang berasal dari kata phileinsophia kemudian menjadi philosophia, memiliki makna 'cinta (mencintai) pada kebijaksanaan' (love of wisdom). Sedangkan kata "filosof" (filsuf) berarti 'pencinta atau pencari kebijaksanaan'.

Kata "cinta" memiliki arti yang luas, cinta dapat berarti keinginan, ingin atau cita-cita. Seseorang yang memiliki cinta atau keinginan akan berusaha menggapai sesuatu yang diinginkan, atau akan berusaha meraih yang dicintai. Sedangkan, kata "kebijaksanaan" memiliki arti yang lebih luas. Dalam kamus besar bahasa Indonesia, kata "kebijaksanaan" memiliki beberapa pengertian, yaitu selalu menggunakan akal budi (pengalaman dan pengetahuannya), arif, cakap, cermat, pandai dan hat-hati. Dari beberapa pengertian tersebut, dapat disimpulkan bahwa kebijaksanaan adalah pengetahuan dan kepandaian yang mendalam. Secara sederhana, "cinta kebijaksanaan" atau filsafat dapat dipahami sebagai keinginan untuk mengetahui sesuatu secara mendalam.

Filsafat adalah sebuah studi tentang seluruh fenomena kehidupan dan pemikiran manusia secara kritis dan dijabarkan dalam konsep mendasar. Filsafat tidak didalami dengan melakukan eksperimen dan percobaan, tetapi dengan mengutarakan masalah secara persis, mencari solusi untuk itu, memberikan argumentasi, dan 
alasan yang tepat untuk solusi tertentu. Akhir dari proses-proses itu dimasukkan ke dalam sebuah proses dialektika. Untuk studi falsafi, mutlak diperlukan logika berpikir dan logika bahasa. Logika merupakan sebuah ilmu yang sama-sama dipelajari dalam matematika dan filsafat. Hal itu membuat filsafat menjadi sebuah ilmu yang pada sisi tertentu berciri eksak disamping nuansanya filsafat masih ada, yakni spekulasi, keraguan, rasa penasaran dan ketertarikan. Filsafat juga bisa berarti perjalanan menuju sesuatu yang paling dalam, sesuatu yang tidak dapat disentuh oleh disiplin ilmu lainnya dengan sikap skeptis yang mempertanyakan segala hal.

Dasar filsafat sebagai studi tentang seluruh fenomena kehidupan dan pemikiran manusia secara kritis dan dijabarkan dalam konsep mendasar diantaranya ontologi, aksiologi dan epistemologi. Ontologi merupakan ciri-ciri esensial dari yang ada dalam dirinya yang berbeda dari studi tentang hal-hal yang ada secara khusus. Dalam mempelajari yang ada dipelajari bentuknya yang sangat abstrak. Aksiologi merupakan studi yang menyangkut teori umum tentang nilai, suatu nilai yang menyangkut segala yang bernilai. Aksiologi juga merupakan studi filosofi tentang hakikat nilai-nilai. Epistemologi berasal dari bahasa Yunani, yaitu episteme artinya pengetahuan dan logos artinya ilmu. Jadi epistemologi adalah ilmu pengetahuan tentang informasi.

Menurut Kattsoff (2004:3), mempelajari filsafat membawa kita kepada pemahaman dan tindakan. Filsafat tidak seperti membuat roti, istilah ini disampaikannya pada bukunya yang berjudul Pengantar Filsafat. Meskipun tidak membuat roti, namun filsafat dapat menyiapkan tungkunya, menyisihkan noda-noda dari tepungnya, menambah jumlah bumbunya secara layak dan mengangkat roti itu dari tungku pada saat yang tepat. Secara sederhana hal ini berarti bahwa tujuan filsafat ialah mengumpulkan pengetahuan sebanyak mungkin dan menerbitkan serta mengatur semua itu didalam bentuk yang sistematis. Filsafat membawa kita kepada pemahaman, dan pemahaman membawa kita kepada tindakan yang lebih layak. Ilmu filsafat berisi tentang teori-teori filsafat dari para filsuf tidak berbeda dengan ilmu-ilmu yang lain, seperti ilmu pendidikan yang berisi tentang teori-teori pendidikan, ilmu sejarah yang berisi teori-teori sejarah, ilmu sastra yang berisi teori-teori sastra dan seterusnya. Jadi mempelajari filsafat adalah belajar mengenai teori-teori filsafat.

\subsection{Manusia Menurut Perspektif Hindu}

Dalam Sārasamuccaya disebutkan tentang bagaimana beruntungnya menjelma dan lahir menjadi seorang manusia di dunia ini. Karena dengan dilahirkan menjadi manusia, maka seseorang dapat menolong dirinya dari keadaan sengsara (reinkarnasi berulang-ulang) dengan jalan berbuat baik, seperti yang tersurat dalam Sārasamuccaya 3 dan 4 berikut ini:

Ri sakwehning sarwa bhuta, iking janma wwang

juga wenang gumawayaken ikang

śubhāsubhakarma, kuneng panentasakena ring

subhakarma juga ikangasubhakarma phalaning dadi wwang

Terjemahannya:

Diantara semua makhluk hidup, hanya yang dilahirkan menjadi manusia sajalah yang dapat melaksanakan perbuatan baik ataupun buruk, leburlah ke dalam perbuatan baik, segala perbuatan yang buruk itu; demikianlah gunanya (pahalanya) menjadi manusia

Apan iking dadi wwang, uttama juga ya, Nimittaning mangkana, wenang ya tumulung Awaknya sangkeng sangsāra, makasadhanang

Subhakarma, hinganing kottamaning dadi wwang ika

Terjemahannya:

Menjelma menjadi manusia itu adalah sungguh-sungguh utama; sebabnya 
demikian, karena ia dapat menolong dirinya dari keadaan sengsara (lahir dan mati berulang-ulang) dengan jalan berbuat baik. Demikianlah keuntungannya dapat menjelma menjadi manusia.

Sārasamuccaya menganjurkan agar mempergunakan dengan sebaik mungkin kesempatan menjelma menjadi manusia, karena kelahiran dengan menjelma menjadi manusia adalah kesempatan yang sangat sulit dan langka untuk diperoleh. Menggunakan tubuh materi manusia sebagai jalan menuju alam sorga, sangat dimungkinkan untuk mencapai kesadaran spritual, maka dari itu segala perbuatan, pikiran dan perkataan yang menyebabkan kita semakin terikat dengan dunia maya dan ketidakbenaran sudah seharusnya untuk dihindari. Sebab kelahiran menjadi manusia adalah kesempatan melakukan karma (kerja) baik ataupun kerja buruk, yang hasilnya akan dinikmati di akhirat. Artinya, kerja baik ataupun kerja buruk sekarang ini sebagai wujud karma hasilnya akan nanti dirasakan saat di akhirat.

Sesungguhnya kelahiran menjadi manusia ibaratnya seperti gerlapan kilat di langit. Artinya pendek dan cepat keadaannya itu dan amat sulit untuk memperolehnya, oleh karena itu gunakanlah sebaik-baiknya kesempatan menjadi manusia untuk melakukan dharma, yang menyebabkan musnahnya proses lahir dan mati, sehingga berhasil mencapai sorga. Seperti yang tersurat dalam kitab Sārasamuccaya 8 berikut ini:

Iking tang janma wwang, ksanikaswabhāwa ta ya

Tan pahi lawan kedapning kilat, durlabha towi,

Matangnyan pongakenayari kagawayanning

Dharmas adhāna, sakarananging manāsanang sangsāra

Swargaphala kunang

Selain itu perspektif eksistensi manusia juga terdapat didalam teks Bhuana Kosa. Dalam teks ini Tri Guna sebagai tiga sifat dasar yang dimiliki oleh manusia dibawa manusia sejak ia lahir. Tri
Guna ini akan saling bergantian mempengaruhi manusia, hal ini dapat dijelaskan dari adanya konsep Tri Guna ini dalam lontar Bhuana Kosa IV. 20, sebagai berikut :

Satwa, rajah, tamah, yeka tri guna, nga, wiparita nirguña,

ya ta hetuning jagat tan wĕtu sakaring abyakta, wiparita ngaranya,

yan satwa utkața, dadi manușa, yang tamah utkata,

dadi tiryyak tika, nahan ta kramanya.

Terjemahannya :

Sattwam, Rajah, Tamah disebut dengan Triguna, mempunyai sifat bingung, tanpa keahlian. Itulah sebabnya alam yang lahir dari abyakta dikatakan mempunyai sifat bingung. Bila Satwam yang unggul, maka akan menjadi manusia. Bila tamah yang unggul, maka akan menjadi binatang, demikian keadaannya.

Sloka tersebut memberikan penjelasan bahwa adanya Tri Guna ini, akan saling bergatian satu dengan yang lainnya untuk mempengaruhi watak manusia tersebut. Adanya Tri Guna ini tentunya harus dapat dipelajari dan dipahami dengan baik, agar nantinya dari Tri Guna, dapat menyebabkan diri manusia tersebut masuk ke alam sorga bukan sebaliknya kea lam neraka, dan Tri Guna ini juga berfungsi untuk memikirkan apakah selama hidup, manusia tersebut sudah melaksanakan kebaikan atau tidak.

Untuk mencapai sorga dan mencapai kelepasan serta menghilangkan kesengsaraan penjelmaan seseorang perlu mempelajari pengetahuan yang benar, salah satunya tentang nilai-nilai kearifan lokal, seperti pada teks Sang Hyang Tattwa Jnana. Dalam teks Tattwa Jnana disebutkan:

Nihan kayatnākna de sang sewaka dharma, mahyun luputeng janma sangsāra, hana śanghyang tattwa jñāna ngaranira, yatika kwruhakênanta rumuhun, lawanika dewatānya enak pwa wruh ta ring Sanghyang tattwa jñāna, niyata sira tumon janma 
sangsara mwang mantuka ri sangkaya. Aparan ika sinanggah Sanghyang tattwa jñ̄ana ngaranira, sugyan mangkana linga sang para, anampih Sanghyang tattwa jūāna ngaranira, anung pinaka bungkah ning tattwa kabeh, ngya Iwirnya nihan

(Tattwa Jnana, 1)

Terjemahannya :

Inilah yang patut diperhatikan oleh seorang abdi dharma, yang ingin bebas dari kesengsaraan penjelmaan. Ada Sanghyang Tattwa Jñāna namanya, itulah hendaknya engkau ketahui terlebih dahulu, beserta dewatānya. Hendaklah engkau akan memahami kesengsaraan penjelmaan ini dan akan kembali ke asalnya. Apakah yang disebut sanghyang tattwa jñāna itu? Barangkali demikianlah pertanyaan orang kebanyakan. Hanya ada Sanghyang Tattwa jñāna namanya yang menjadi dasar semua tattwa. Manakah itu? Demikian.

Penjelmaan berulang-ulang dengan menggunakan tubuh jasmani manusia menyebabkan kesengsaraan yang terus menerus. Pengetahuan akan kesadaran dan kelepasan perlu terus dipelajari dan dipahami sehingga nantinya dengan dasar pengetahuan maka kesadaran spiritual akan diperoleh. Teks tattwa jnana menganjurkan agar brata, tapa, yoga, samādhi terus dilakukan guna mencapai kesadaran spritual. Pada waktu bersamādhi sang ātmā wiśeșa memuja Sanghyang İ́swara (Tuhan). Perenungan yang mendalam melalui meditasi pada Sang Hyang Iswara ini perlu dilakukan dalam melepaskan keterikatan karma dan mencapai-Nya.

\subsection{Hakikat Manusia}

Terdapat beberapa aliran didalam filsafat manusia yang memiliki pandangan tentang hakikat atau esensi manusia. Menurut Abidin (2006:25) dari sekian banyaknya aliran, terdapat dua aliran utama yang terbesar dan tertua, yaitu materialisme dan idealisme. Materialisme adalah suatu paham filsafat yang meyakini bahwa esensi kenyataan, termasuk hakikat manusia bersifat material atau fisik. Ciri utama dari kenyataan fisik atau material adalah bahwa ia menempati ruang dan waktu, memiliki keluasan dan bersifat objektif, maka ia bisa diukur, dihitung, diobservasi. Sedangkan alam spiritual atau jiwa, yang tidak menempati ruang, tidak dapat disebut sebagai sebuah hakikat atau esensi dari kenyataan, oleh karena itu ditolak keberadaannya.

Para materialis percaya bahwa tidak ada kekuatan apa pun yang bersifat spritual di balik gejala atau peristiwa yang bersifat material itu. Kalau ada peristiwa atau gejala yang masih belum diketahui, atau belum bisa dipecahkan oleh manusia, maka hal itu bukan berarti ada kekuatan yang bersifat spritual di belakang peristiwa tersebut, melainkan karena pengetahuan dan akal kita saja yang belum dapat memahaminya. Karena sangat percaya pada hukum kausalitas, maka golongan materialis pada umumnya sangat deterministik. Mereka tidak mengakui adanya kebebasan atau independensi manusia. Seorang materialis sangat yakin bahwa tidak ada gerak atau perilaku yang ditimbulkan oleh dirinya sendiri.

Gerak selalu bersifat mekanis yang digerakkan oleh kekuatan-kekuatan di luar dirinya. Gerak benda dan tingkah laku hewan serta manusia, tidak digerakkan oleh dirinya sendiri atau mencapai tujuan-tujuan yang ditentukan oleh dirinya sendiri, melainkan oleh kekuatan-kekuatan di luar dirinya. Oleh sebab itu, metafor yang digunakan oleh materialisme untuk menjelaskan gerak atau perilaku adalah mesin dan benda-benda yang bersifat mekanis dan memberikan bantuan bagi kemudahan kehidupan manusia. Manusia merupakan makhluk yang deterministik, tidak memiliki kebebasan. Perilaku manusia tidak lain adalah akibat dari suatu sebab yang berada di luar dirinya (eksternal). Perilaku manusia tidak berasal dari dirinya sendiri. Manusia berperilaku karena ada suatu sebab yang mendahuluinya, hingga pada akhirnya menuntut untuk diberikan respons atau reaksi. 
Kebalikan dari materialisme adalah idealisme. Menurut aliran ini, kenyataan sejati adalah bersifat spiritual. Oleh sebab itu aliran ini disebut dengan aliran spritualisme. Para idealis percaya bahwa ada kekuatan spiritual dibalik setiap kejadian. Esensi dari kenyataan spiritual ini adalah berpikir. Karena kekuatan atau kenyataan spiritual tidak dapat diukur atau dijelaskan berdasarkan pada pengamatan empiris, maka kita hanya bisa menggunakan metafor kesadaran manusia. misalnya kekuatan spiritual dianggap bersifat rasional, berkehendak, berperasaan, kreatif dan sebagainya.

Bagi kaum idealis, kesadaran manusia berfungsi untuk menjelaskan kenyataan sejati. Karena para idealis merasa kesulitan untuk menjelaskan kebenaran yang ada di balik penampakan lahiriah, sehingga perlu adanya kesadaran manusia untuk mendukung dalam menjelaskannya. Dengan diakuinya kenyataan sejati yang bersifat spiritual, tidak berarti bahwa para idealis menolak kekuatan-kekuatan yang bersifat material (fisik) dan menolak adanya hukum alam. Seperti halnya kesenian dan kebudayaan merupakan manifestasi lahiriah dari jiwa manusia, alam fisik pun adalah manifestasi lahiriah dari kenyataannya yang sejati, yakni Tuhan. Para idealis percaya adanya gerak pada alam yang mengatur peredaran dan perputaran planet di alam semesta. Baik gerak planet-planet maupun hukum alam telah ada yang mengaturnya dengan kekuatan spiritual.

Seperti halnya perbuatan manusia yang memiliki tujuan, setiap gerak atau peristiwa alam pun pasti memiliki tujuan. Setiap peristiwa tidak mungkin terjadi begitu saja sebagai sesuatu yang kebetulan, melainkan telah diatur dan direncanakan oleh kekuatan spiritual dan memiliki tujuan-tujuan tertentu (teleologis). Jika perbuatan manusia diarahkan pada nilai-nilai atau norma-norma, maka hidup manusia adalah bertujuan, yakni hendak menggapai dan sekaligus mengaktualisasikan nilai, norma atau hukum. Perilaku manusia mengandung maksud dan tujuan, bukan sematamat bergerak secara mekanis. Sumber penggerak utama perilaku manusia bukan kekuatan eksternal (aksi-reaksi) melainkan kekuatan internal, yakni jiwa yang hendak mewujudkan dirinya dalam menggapai nilai-nilai pribadinya dan normanorma atau hukum-hukum masyarakat agamanya. Dengan demikian tujuan hidup manusia adalah untuk mengaktualisasikan diri dan nilai-nilai yang diyakininya.

Perbuatan manusia merupakan hasil dari jiwa yang telah mengekspresikan dirinya, maka perilaku harus dipahami sebagai sebuah simbol dari ekspresi kegiatan jiwa. Tubuh jasmani harus dipahami sebagai sarana bagi jiwa dalam mengekspresikan dirinya, baik dalam bentuk perilaku yang langsung maupun tidak langsung seperti dalam bentuk kebudayaan dan kesenian.

Sejumlah besar penganut paham idealisme memiliki pandangan deterministik mengeni manusia. mereka menyatakan roh absolut (Tuhan) adalah bebas dan tidak terhingga, tetapi manusia sebagai bagian atau perwujudan dari Tuhan sifatnya tidak bebas dan terhingga. Baik kedudukan dan tindakan manusia telah diatur atau ditentukan oleh Tuhan. Tidak ada kebebasan manusia, baik secara individual maupun kolektif, karena kebebasan manusia adalah kebebasan roh absolut. Roh absolut inilah yang dalam perspektif Hindu dikenal dengan sebutan atman.

\subsection{Tahap Eksistensi Manusia}

Ada tiga tahapan eksistensi manusia saat dilahirkan didunia ini, baik saat tubuh fisik mengalami proses stimulus dari dunia luar (eksternal) maupun tubuh spritual memandang segala sesuatu yang berada di dalam dirinya sendiri (internal). Adapun tahapan-tahapan tersebut antara lain sebagai berikut:

1. Tahap Estetis

Tahap estetis adalah tahap dimana orientasi hidup manusia sepenuhnya diarahkan untuk mendapatkan 
kesenangan. Pada tahap ini manusia dikuasai oleh naluri-naluri seksual, oleh prinsip-prinsip kesenangan, yang biasanya bertindak menurut suasana hatinya. Manusia estetis adalah manusia yang hidup tanpa jiwa, tidak memiliki akar dan isi didalam jiwanya. Kemauannya adalah mengikat diri pada kecendrungan masyarakat dan jamannya yang menjadi trend dalam masyarakat menjadi petunjuk hidupnya. Manusia estetis hidup untuk dirinya sendiri, untuk kesenangan dan kepentingan pribadinya. Kesemuanya itu tidak dilandasi oleh passion apapun, selain keinginan untuk sekedar mengetahui dan mencoba. Hidupnya tidak mengakar dalam, karena dalam pandangannya, pusat kehidupan ada di dunia luar. Manusia estetis adalah manusia yang pada akhir hidupnya hampir tidak bisa lagi menentukan pilihan, karena semakin banyak alternatif yang ditawarkan masyarakat dan jamannya.

2. Tahap Etis

Pada tahapan ini manusia yang tadinya masuk pada tahapan estetis menjadi tahap etis adalah seseorang yang mengalami "refleksi diri" atau kesadaran, dimana individu mulai menerima kebajikan-kebajikan moral dan memilihuntuk mengikatkan dirinya kepadanya. Prinsip kesenangan mulai ditinggalkan dan saat ini seseorang mulai menyadari untuk menerima dan menghayati nilai-nilai kemanusiaan yang bersifat universal. Telah mulai ada hasrat dalam menjalani kehidupan berdasarkan nilai-nilai kemanusiaan yang dipilihnya secara bebas. Jiwa seseorang sudah mulai terbentuk sehingga hidupnya tidak lagi tergantung pada masyarakat dan jamannya. Akar kehidupannya ada di dalam dirinya sendiri dan pedoman hidupnya adalah nilai-nilai kemanusiaan yang lebih tinggi.
3. Tahap Religius

Perpindahan dari tahapan etis ke tahapan religius adalah perpindahan dari rasa ke akuan dan meleburkan diri kedalam realitas Tuhan. perpindahan dari tahap etis ke tahap religius lebih sulit daripada perpindahan dari tahap estetis ke tahap etis. Jika perpindahan dari tahap estetis ke tahap etis membutuhkan rasional dan pertimbangan segala konsekuensi yang akan kita hadapi, maka pada perpindahan dari tahap etis ke tahap religius nyaris tanpa pertimbangan rasional. Perbedaan lainnya terletak pada obyektivitas dan subyektivitas nilai. Nilai-nilai kemanusiaan pada tahap etis masih bersifat obyektif sehingga ada rujukan yang bisa diterima baik secara rasional maupun secara akal sehat. Sebaliknya, nilainilai religius bersifat murni subyektif, sehingga seringkali sulit diterima akal sehat. Tidak mengherankan kalau sikap dan perilaku manusia religius sering dikatakan gila atau tidak masuk akal. Memutuskan untuk masuk ke dalam ranah Tuhan ibaratnya memasuki sebuah hutan yang luas dan tak berujung. Sebelum memasukinya akan timbul perasaan yang cemas dan takut, jangan-jangan keputusan yang diambil hanyalah keputusan yang sia-sia dan malah menjadi bahaya bagi diri sendiri. Hanya dengan keyakinan pribadi yang berlandaskan sraddha atau iman, seseorang berani meleburkan dirinya ke dalam diri Tuhan dengan rasa aman dan bahagia. Hidup seseorang akan berakhir dalam kebahagiaan abadi, kalau ia sudah berada dalam tahap eksistensi yang religius. Karena didalam tahapan ini ia mulai untuk menerima dan mengikuti jalan Tuhan dan tidak lagi terikat pada tahap etis (nilai-nilai kemanusiaan) maupun pada tuntutan pribadi, masyarakat dan jaman (tahap estetis). 


\section{SIMPULAN}

Pengetahuan hakikat manusia adalah mempelajari dan memahami tentang keberadaan atau eksistensi diri dengan mempraktekkannya dalam kehidupan sehari-hari, baik secara material maupun spiritual. Lalu kemudian membandingkan keduanya dan mengambil kesimpulan jalan mana yang paling baik ditempuh dalam hidup kita sesuai dengan tiga tahapan di atas (tahap estetis, tahap etis dan tahap religius). Apakah kita sudah nyaman dengan tahapan estetis yang selalu menggunakan panca inderanya untuk melayani tuntutan pribadi, masyarakat dan jaman? atau dengan tahapan etis (praktek dengan mempertimbangkan nilai-nilai kemanusiaan) ataukah pada tahap religius yang meleburkan diri kepada pengetahuan realitas Tuhan sebagai peng"ada" dari segala yang ada di dunia ini. Semua dikembalikan pada kita sendiri.

\section{DAFTAR PUSTAKA}

Abidin, Zainal. 2006. Filsafat Manusia. Bandung: Remaja Rosdakarya.

Kattsoff, Louis. 2004. Pengantar Filsafat. Yogyakarta: Tiara Wacana

Kajeng, I Nyoman. 2005. Sārasamuccaya. Surabaya: Paramita.

Mantra, Ida Bagus. 1994. Bhagawad Gìtà. Bali: Pemerintah Daerah Tingkat I.

Pudja, G., Rai Sudharta, Tjokorda. 2003. Manawa Dharmasastra (Manu Dharmasastra). Jakarta: Mitra Jaya. 